Cahiers $d u$ MONDE RUSSE

\section{Cahiers du monde russe}

Russie - Empire russe - Union soviétique et États indépendants

$56 / 4 \mid 2015$

Médiateurs d'empire en Asie centrale (1820-1928)

\title{
Sarah Davies, James Harris, Stalin's World, Dictating the Soviet Order
}

\section{David Shearer}

\section{OpenEdition \\ Journals}

Édition électronique

URL : http://journals.openedition.org/monderusse/8259

DOI : $10.4000 /$ monderusse. 8259

ISSN : $1777-5388$

Éditeur

Éditions de l'EHESS

\section{Édition imprimée}

Date de publication : 1 octobre 2015

Pagination : 861-864

ISBN : 978-2-7132-2507-9

ISSN : $1252-6576$

Référence électronique

David Shearer, «Sarah Davies, James Harris, Stalin's World, Dictating the Soviet Order », Cahiers du monde russe [En ligne], 56/4 | 2015, mis en ligne le 01 octobre 2015, Consulté le 24 septembre 2020. URL : http://journals.openedition.org/monderusse/8259; DOI : https://doi.org/10.4000/monderusse. 8259

Ce document a été généré automatiquement le 24 septembre 2020.

2011 


\title{
Sarah Davies, James Harris, Stalin's World, Dictating the Soviet Order
}

\author{
David Shearer
}

\section{RÉFÉRENCE}

Sarah DAVIES, James HARRIS, Stalin's World, Dictating the Soviet Order, New Haven :

Yale University Press, 2014, 360 p.

1 Sarah Davies and James Harris have set themselves the task of trying to understand Stalin. They do this primarily through an examination of the kinds of information that Stalin had at hand, and through which he viewed the world. These two authors have spent years collectively culling and sifting through now available documents from Stalin's personal archives-the mass of daily reports prepared for his reading, private correspondence, drafts of speeches, texts, marginal comments on texts, and editing and editorial notes, among other sources. The authors also include several hitherto unpublished diaries of people close to Stalin, or who worked with him in various capacities. In these documents, argue the authors, lies the secret to understanding Stalin. Stalin, as they argue, was a man of words, literally, as well as action, and the key to understanding his actions are in his words. Words mattered to Stalin, and it was through words-words that he both read and wrote-that Stalin understood and attempted to fashion the world that he oversaw. By comparing Stalin's actions with the information he received, and through his marginalia and writings, Davies and Harris believe that they can say something definitive about how Stalin perceived and misperceived the world about him, and how his thinking evolved over time. One might argue this or that point, but, by and large, their book is convincing. The chapters are clearly conceptualized and well grounded in historiography. The writing is straightforward and accessible.

2 Davies and Harris divide their book into two sections. The first section of three chapters focuses on the kinds of information that Stalin received, and how he filtered 
and interpreted that information. In the first chapter, the authors discuss Stalin's view of leadership, and especially his increasingly jaundiced view of the Party apparatus. Chapters two and three focus on Stalin's penchant for seeing spies and saboteurs everywhere, and his constant fear of capitalist encirclement and potential war. In the second section of the book, Davies and Harris discuss how Stalin managed his leadership cult, his changing views of Soviet society and its stratification, and his various pronouncements on culture, art, and socialist realism. This second section is based not so much on information that Stalin received as on a close reading of his various unpublished writings and notes, emendations, correspondence, and editorial comments. In both sections, the Stalin who emerges is a far more sophisticated and subtle thinker than Trotsky's Stalin-a power hungry bureaucratic schemer, a man of narrow vision and low cunning. Davies and Harris portray Stalin's worldview as a mixture of preconceived ideas, but also pragmatic flexibility. His thought was far from static. His thinking about state building, domestic and international politics, economic management, class and society, and culture evolved: it was "multifaceted," often adaptable, and at times sophisticated. Stalin read enormous amounts of material, and he paid close attention to words and their meaning and, as others have also pointed out, he spent an enormous amount of time finding just the right words to try to craft and mold a Soviet Union in his image. This is why we must pay close attention to Stalin's words, argue Davies and Harris. It is Stalin's words, especially his changing use of words, that give us insight into his vision of the world.

Three arguments stand out in this book, the first of which is perhaps the weakest of the three. In the first chapter, "Bolshevik' Leadership," Davies and Harris detail Stalin's attempts to fashion an economic and political leadership cadre from at least the mid-1920s through the 1930s, and they trace his growing frustration with that group. This chapter traces Stalin's growing dissatisfaction with regional subordinates who were either too heavy handed-too authoritarian-and therefore ineffective, or more often than not, engaged in passive avoidance, foot-dragging, and outright falsification, all the while pretending that they were fulfilling central directives. Stalin refused to accept that his own overly ambitious plans fostered exactly these kinds of coping responses, and he blamed lower party leaders for the inevitable and massive failures in agrarian and industrial policies of the 1930s. Davies and Harris argue that Stalin's frustration built to a crescendo in the late 1930s. Once his power became unassailable, Stalin engaged in a massive purge of what he believed to be incompetent and "double-dealing," hypocritical managers. Here, according to the authors, is the explanation for the great purges of the late 1930s. As the authors write, "[b]ecause the coping behavior was so pervasive, the political violence directed against economic officials was doomed to be devastating." (20). The book's discussion of how Stalin's own policies created a dysfunctional bureaucracy is clear and rings true. It was true also that Stalin was frustrated by what he regarded as a lethargic and complacent nomenklatura. At the same time, such a mono-causal explanation of the great purges of 1936-1938 gives short shrift to more overt political interpretations. The latter center on Stalin's desire to rid himself of a generation of political elites who he feared had become too ensconced in their own power networks, and who posed a potential threat to Stalin's rule. [See, for example, Oleg Khlevniuk, “The First Generation of Stalinist 'Party Generals"' in E.A. Rees, ed., Centre-Local Relations in the Stalinist State, 1928-1941 (Basingstoke: Palgrave, 2002), 37-64)]. 
The second argument put forward in the book is much stronger than the first, and revolves around the authors' assertion that, given the realities of the times, Stalin was not simply delusional or cynically manipulative about conspiracies. His paranoia had a basis in reality. Davies and Harris develop this line of argument in chapters two and three, on spy mania and capitalist encirclement. These are two of the best chapters in the book, as the authors point out that Stalin had good reason to fear conspiracies. Zinov'ev and Kamenev did, indeed, want to replace him as head of the ruling Communist Party and the country. Trotskii was a real enemy and, in the early 1930s, boasted that he would work within and without the USSR to bring down Stalin. As Davies and Harris also point out, it was no secret that capitalist countries were hostile to the Soviet Union. They did, in fact, engage in spying, lots of it, and they supported insurgent groups inside the Soviet Union. Stalin did not need to invent enemies. There were plenty enough of those. Where he was mistaken, according to the authors, was to see all of these enemies acting in concert, and in seeing every event-foreign or domestic-as part of that single large conspiracy.

Davies and Harris explain Stalin's misperception of coordinated and ongoing conspiracy as a genuine misperception, not as a tactical strategy to divert blame for overzealous policies, or as a ploy to mobilize mass support for overly ambitious industrialization policies. The leader's penchant to see ever widening and omnipresent conspiracies resulted from several influences: his own conspiratorial activities as a revolutionary, the ruthless conflicts of his civil war experience, Bolshevik ideology and political culture, party power struggles, and the hostile international climate of the 1920s and 1930s. Most important of all, however, according to Davies and Harris, was a multi-centered and overlapping information system designed specifically to seek out and identify hostile intents and actions. The domestic and international branches of the political police, the diplomatic corps, and news agencies, especially Tass, all operated to feed Stalin with the kind of information that he was predisposed to expect: conspiracy and more conspiracy. Davies and Harris are at their best in chapters two and three as they detail how Stalin viewed and wove together various events-foreign and domestic-that were often unconnected, but that Stalin put together in a way to confirm what he wanted to believe. The murder of the Soviet diplomat P. Voikov, for example, in Warsaw in June 1926, is the classic example. The Soviet foreign minister at the time, Chicherin, understood the murder for what it was, a singular event by a disgruntled anti-Bolshevik émigré. Stalin, however, saw the secret machinations of Britain, France, Poland, and even Romania behind the murder, all acting together to try to provoke a war. Voikov's murder and Stalin's interpretation are well known, but Davies and Harris show that Stalin's fear of war was not just episodic or a cynical tactic to entrap political opponents. Stalin's fear and sense of vulnerability was consistent from the early 1920s until 1941. The German invasion of that year seemed to confirm nearly two decades of misperceptions about concerted and secret foreign intentions to destroy the USSR. Stalin's fears had a basis in fact, argue Davies and Harris, although Stalin, relying on a biased information system, exaggerated the scale and coordination of that threat. As the authors note, Stalin built a strong Soviet Union, but he perceived his position and the defense of the country to be in constant jeopardy. The Stalinist state was strong, conclude Davies and Harris, but Stalin perceived it to be weak.

The third, and one of the most interesting, arguments of this book focuses on Stalin's evolution of thinking about class and society in the Soviet Union. Chapter five, "The 
Working Class," shows well the fruitfulness of the authors' approach in deriving Stalin's thought processes from his verbal and written comments. In this chapter, Davies and Harris follow Stalin's thinking about working class hegemony, from his belief in class struggle and proletarian dictatorship in the 1920 s and early 1930 s to a broader, more inclusive idea of Soviet society by the mid and late1930s. The authors follow this transformation in the leader's thinking by examining Stalin's close editing of party slogans, literature, newspaper and other media coverage, and his own history of the Communist Party. By the late 1930s, with the victory of socialism supposedly secured in the USSR, Stalin promoted a vision of Soviet society not as one dominated by working-class hegemony and riven by class conflict, but as a "cohesive" community, a socialist whole (276-277). That community included workers (though not a working class, as such), but was increasingly dominated by a specifically sovietized kind of intelligentsia made up of educated managers, literate specialists, and cultural workers. Stalin perceived Soviet society as a work still in progress, but by the end of the 1930s, it was, he believed, cohering into something more than just a conglomeration of peasants, workers, and an intelligentsia. After the war, as Davies and Harris note, Stalin no longer referred to the proletariat, or to peasants, but to Soviet citizens. His careful excising of class language from party and state slogans reveals a significant change in the dictator's thinking about the Soviet sotsium.

In their final chapter, "Soviet Culture," Davies and Harris discuss Stalin's various pronouncements about socialist realism, and what it meant. By looking at what Stalin actually wrote or said, the authors conclude that, in Stalin's thinking, socialist realism was a flexible series of guidelines rather than a set of dogmatic precepts. At times, his comments or letters seemed to confirm a narrow, didactic interpretation, as in his famous comments that music should be written with a clear melody, or that story lines should be simple, moralistic, and grandly heroic. As often as not, though, Stalin criticized many works that he believed were too simplistic, too black and white, and that did not reflect the complexities of life as it was lived by ordinary people. Davies and Harris acknowledge the apparent contradictions in many of Stalin's pronouncements, but they see this as evidence that Stalin's views about Soviet culture were more sophisticated and flexible than previously thought. This may be the case, but one might read these contradictory statements in another way: not as a sign of flexibility, but as evidence of Stalin's manipulation of culture toward whatever political ends suited him at a particular moment. In either case, this chapter, and this book, give pause for a reassessment of Stalin. It is a work full of interesting and fresh assessments, and it should generate a number of new research leads in the history of the Stalinist dictatorship.

\section{AUTEURS}

\section{DAVID SHEARER}

University of Delaware 